\title{
FORMATION AND IMPLEMENTATION OF MARKET STRATEGY IN THE STRUCTURE OF THE PORT'S BUSINESS MECHANISM
}

\author{
Svitlana Ilchenko \\ Department of Transport Market \\ Institute of Market, Economic and Environmental Research of Ukraine, \\ 29 Frantsuz'kyi blvd., Odessa, Ukraine, 65044 \\ CV-2010@yandex.ua \\ Anna Glushko \\ Department of Transport Market \\ Institute of Market, Economic and Environmental Research of Ukraine, \\ 29 Frantsuz'kyi blvd., Odessa, Ukraine, 65044 \\ Ukf08@mail.ru
}

\begin{abstract}
In a market economy oriented to economic management methods, the issue of solving the problems of constructing mechanisms and defining certain research tools for a unique market strategy of an enterprise, the formulation of the principles for its formation and implementation, becomes especially topical. The article provides an integral view of the procedure and specifics of the formation of a market strategy for enterprises in the port area, separate ways to implement it and improve the competitiveness of the entire port.
\end{abstract}

Keywords: competitiveness of port enterprises, market strategy of ports, principles of formation of long-term plans.

\section{Introduction}

To study such complex and multi-sided notion as a market strategy, it is necessary, in our opinion, to apply a systematic approach that involves considering a market strategy as an integral object - building a life system; identification of factors that determine the market strategy; study of interrelations and interdependencies between system-forming factors; identification of the conditions for the implementation of the market strategy of the enterprise as a system and so on.

\section{Literature review}

Separation of this research topic is caused by a number of problems that are directly decisive in the formation of long-term programs for the development of enterprises of the domestic port area. The availability of sufficient scientific and professional research is an important basis for the final decision of the operating enterprises of this industry. However, it is the generalization of developments, taking into account the most significant problems in the construction of effective programs and strategies for the development of Ukrainian ports, and is still on the agenda of experts.

Speaking about the market strategy of the enterprise, it is necessary to keep in mind a set of methods for effectively implementation of the economic potential of the enterprise's economic mechanism. In the economic literature $[1,2]$, there are approaches aimed at determining the meaningful characteristics of a market strategy associated with the assessment of productivity of resource use, alternative cost, associated costs and losses, conditions for mutual alignment of objectives with the position of preventing insolvency (bankruptcy) of the enterprise in the long term. So, for example, considering the problems of effectiveness of achieving strategic goals, A. Gradov believes that the market strategy should include certain rules and techniques [3]. The presented list of rules is quite capacious, and covers, in fact, the whole methodology of business organization from the moment of determination of the mission of the enterprise, that is, in fact, the target orientation of the enterprise, the formation of its production profile and throughout the entire period of operation. However, in our opinion, this list does not contain the systematization of the submitted rules. 
This conclusion is supported by the analysis of the universal scheme proposed in work [4] for the construction of a common market strategy and its constituent elements, implemented in the external and internal environment of the enterprise [3].

Within the framework of the proposed scheme as a component of the market strategy within the external environment of the enterprise, several types of strategies are singled out. To the components of the market strategy of the enterprise, realized in the internal environment of the enterprise, this scheme includes: a strategy for reducing production costs, a strategy for investment activities of the firm, a strategy of the firm's staff. As a generalizing element of the components of the market strategy, a strategy for preventing bankruptcy of an enterprise is proposed. In our opinion, the presented distinction of the elements of the company's strategy looks somewhat artificially, since it is very difficult to distinguish, for example, the strategy of interaction in the money and securities market and the investment strategy of the firm's activity, the pricing strategy and the strategy for reducing production costs. Ultimately, the company's market strategy will be implemented based on specific types of functional activities of the enterprise, implemented in functional strategies.

In the conditions of a market economy, the concept of competitive strategy is closely related to the concept of a company's market strategy [5]. If there is a competitive market and a developed competitive environment, the ability of a significant number of enterprises to survive will determine their competitiveness in the process of enterprises' activity in the market and in competitive conditions [6].

Competitiveness of an enterprise means its ability to withstand competition, that is, it is a potential opportunity for an effective activity of an enterprise in the market to achieve its competitive advantages. In the theory of competitive advantage [7] developed in the studies of M. Popter [8] two types of competitive advantage of the enterprise are distinguished: low costs and differentiation of goods. Low costs reflect the ability of an enterprise to develop products at a lower cost than competitors. The trade features of the enterprise's competitiveness are directly related to the competitive position of products or services and, accordingly, derived from the economic content of this category, are represented by the following definition: "Product competitiveness is understood as its ability to meet the requirements of a specific consumer in a particular market in a time period in terms of quality indicators and consumer costs for the acquisition and operation (or consumption) of this product"[9].

\section{The aim and objectives of research}

The main aim of research is, in its turn, the most comprehensive system that will allow to formulate and implement the market strategy of the enterprise of the port sector in today's changing and highly competitive market conditions.

In a market economy oriented to economic management methods, research of the company's market strategy, namely, the enterprise of the port area and the principles of the formation of this strategy, based on the search for global and local goals, becomes especially relevant. The construction of market strategies is impossible without the formulation and implementation of certain objectives that are associated with taking into account the methods and tools for strengthening the competitive positions of the enterprise through the existing system of levers, incentives, motivational schemes, principles, organizational and economic and legal aspects of building strategies for the development of enterprises in the port sector.

\section{Methodology}

As a theoretical basis of the research, scientific developments and works of leading scientists and specialists of the research field were used. The analysis of existing developments was carried out with the help of general scientific and special methods of abstraction, deduction-induction and a dialectic approach to the definition of significant problems. Identification of patterns and contradictions was achieved using methods of system analysis and synthesis of problems, comparative, logical, generalization, and so on. 


\section{Research results}

There are many classifications of management functions in which, depending on the goals and objectives of the company and in accordance with the chosen market strategy, these or other functions are brought to the fore [10]. For a functioning enterprise, the priority of a strategy is not something frozen, but can change depending on the stage of development of the enterprise and the external environment. Types of competitive advantage make it possible to identify typical strategies for ensuring the competitiveness of an enterprise. The basis of the concept of model strategies is the idea that each of them is based on a competitive advantage, and in order to achieve it, an enterprise must choose its own strategy [11]. The enterprise determines what level of competitive advantage it can and wants to achieve in a certain period of time and in which market (market segment) it is possible. The competitive advantage of an enterprise is determined by the system of values that it can provide its customers. So, in order to obtain a competitive advantage, an enterprise should give buyers the same value system as competitors, but produce goods at a lower cost (a strategy of lower costs), or act so as to give consumers a product with a larger value system, for which it can get a great price (strategy of differentiation).

General characteristics of the company's competitive advantages are formed on the basis of the production profile of the enterprise and the system of signs of competitiveness of the enterprise that is interrelated with it, taking into account the development of competition in the market [12]. Depending on the production profile of the enterprise, a system of signs of its competitiveness is formed.

In the most general form, port strategies [13] can be systematized and presented according to the following scheme (Fig. 1).

The generalization of different points of view on the concept of strategy makes it possible to identify the most important elements that determine its content, to which, in our opinion, should be attributed:

- a set of rules and techniques for achieving goals;

- availability of resources for their implementation in achieving the goals of the system;

- formation of development goals for the whole system.

The market strategy of the port enterprise is realized with the help of its functional strategies. A functional strategy is used to indicate the direction of the activity of a particular functional service within the framework of the implementation of the economic mechanism of the port. Thus, the functional strategy is determined by a set of rules and techniques for achieving the goals of the functional service of the enterprise [14]. At the same time, the functional strategy agreed upon with the market strategy of the firm should presuppose the effective implementation of a specific functional activity of the enterprise's economic mechanism.

One of the most important and significant functional strategies for implementation of an economic strategy for the functioning of the organizational and economic mechanism of an enterprise is a financial strategy [15]. Depending on the level of development of market relations, stability of the country's economy, the financial strategy can take priority among all functional strategies. The financial strategy should be the starting point for the development of other functional strategies, since financial resources are one of the most important criteria limiting the scope and direction of the enterprise. In the process of forming a financial strategy, balancing of all functional strategies and large programs ensuring achievement of the strategic goals of the enterprise is achieved. The formation of the financial strategy is largely interconnected with the functional marketing strategy, as the financial success of the enterprise depends on the correctness of decisions in the field of pricing, targeting certain market segments, the intensity of efforts to promote services on the market, control over the implementation and timely adjustment of marketing policy.

In a market economy, the development of a financial strategy must be preceded by a deep economic analysis of the following information: general economic data, industry statistics and enterprise data [16]. The fluctuations in demand in the industry will affect the value of the company's current assets, accounts receivable, ultimately - the return on equity and the level of financing of the company's long-term and current needs. 


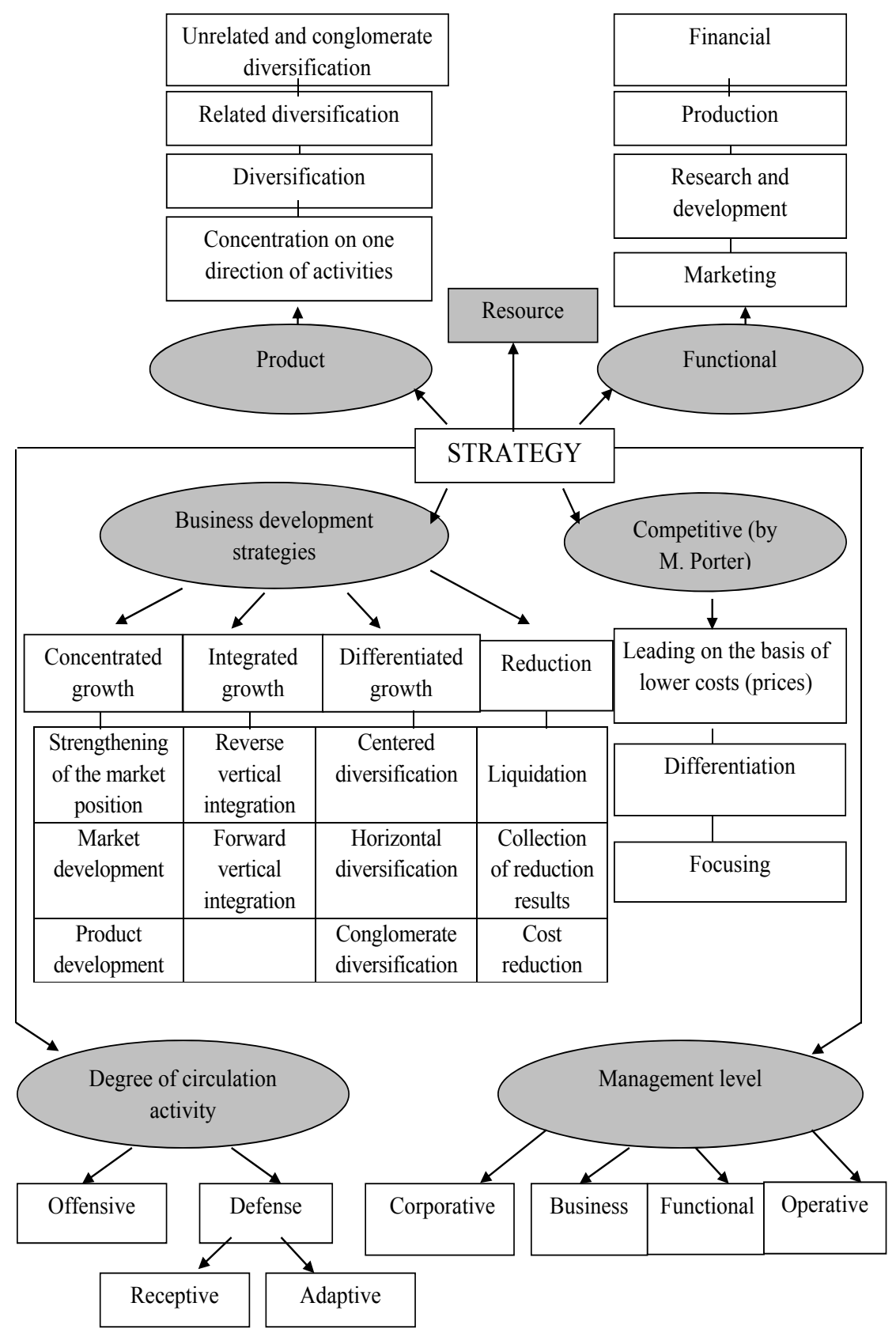

Fig. 1. Classification of the strategies

The algorithm for study of the work of a modern port should consist of the following stages: - analysis of economic activity, which assesses the efficiency of the port's activities, determines "narrow" places and production reserves, factors for reducing costs and increasing profitability, ways to increase labor productivity, the nature of workload and efficiency of the use of fixed production assets;

- determination of financial possibilities of the port assumes measurement of the possibility to pay short-term obligations with consequences; degree of financing at the expense of own means; efficiency of use by the of circulating and fixed capital by the port; profitability of capital; profitability measurement of activities. In the analysis of profitability, a graph of the interaction of constant, variable costs and proceeds from the sale of products is constructed, which, when compared, determines the critical point (profit in which is zero), the profitability threshold and the direction of increase in profits. 
Financial capabilities of the company and the results of the analysis of economic activity determine the actual and future potential of fund formation, the size and sources of implementation of the economic strategy.

Formation of the financial strategy of the port involves the development of long-term and short-term financial plans. The process of preparation of a long-term financial plan includes the following components:

Step I. The capital requirements are determined separately for current and fixed assets and represent the data on the financial means necessary for the expansion, repair, modernization, reconstruction and rationalization of production. The amount of required working capital depends on the total amount of fixed assets and their circulation.

At this stage, the choice of loans is also made, the terms for their receipt are established and the capital in general is divided into own and borrowed (depending on its profitability).

Step II. Within the framework of the financial strategy, an investment strategy is developed on the basis of which an investment plan is subsequently developed.

At this stage, the criteria for making investment decisions are determined depending on the time factor.

There are a number of criteria for making investment decisions taking into account the time factor. In addition, the choice of criteria is influenced by the strategic objectives of the enterprise. If we talk about the criteria for investing, then most often apply the following [17]:

- the net profit from this investment exceeds the net profit from the transfer of funds to the bank deposit;

- the profitability of investments above the level of inflation;

- the profitability of this project, taking into account the time factor (the time value of money) is higher than the profitability of alternative projects;

- the profitability of the assets of the enterprise after the implementation of the project increases (at least, doesn't decrease), and in any case will exceed the average estimated rate on borrowed funds;

- the compliance of the project with the general strategic line of the port, from the point of view of forming a rational structure of production, the time of recoupment of costs, availability of financial sources for covering expenses, ensuring stable long-term receipts and so on.

When analyzing investment projects, we consider it necessary to take into account:

- the riskiness of projects, as the longer the payback period, the riskier the project;

- the time value of money, because over time, money changes its value;

- the attractiveness of projects in comparison with alternative investment opportunities in terms of maximizing the income and property of the company's shareholders at an acceptable level of risk, since this is the main goal for the financial manager.

Currently, investment activities use various methods of analysis and selection of investment projects, each of which allows to review certain characteristics of the project, identify important nuances and details, makes it expedient to use them in a comprehensive manner [17].

The decision to dispose investments is one of the most important decisions of the managers of the enterprise [18]. If an enterprise chooses a strategy aimed at obtaining the advantages associated with a low cost, this will mainly affect the structure of production, investment and development projects associated with improving production efficiency. The enterprise must invest in modern equipment [19]. It is known that high capital intensity of products leads to low profitability in terms of income on invested capital. Compensate for this reduction can be partially by increasing productivity.

In modern conditions, high capital intensity contributes to increased competition, especially when production facilities are not fully used. Production discontinuation can cause big losses and enterprises are trying to fight to the last, usually by setting low (marginal) prices.

This is exactly happening in domestic ports where there is a strong deterioration of equipment and there is a need for significant investment, while the industry is quite capital-intensive and resource-intensive, and as a result, the ports set tariffs at the level of the lower profitability threshold [20]. This, in turn, doesn't provide an opportunity to receive significant profits and investing it in the development of the industry. 
Step III: the preparation of a financial plan for a long-term perspective implies long-term planning of balance liquidity. This planning is based on data on plans for raw materials, labor, production plans and so on.

If the aim of the short-term financial plan is to analyze and control the liquidity situation, the formation of a long-term plan is aimed at the future and is built taking into account the following principles:

- the principle of financial timing - investments with long payback periods should be financed by long-term funds;

- the principle of solvency - planning should ensure solvency at any time;

- the principle of profitability of investments - for all investments it is necessary to choose the cheapest methods of financing. The borrowed capital can be attracted only if it increases the profitability of own funds;

- the principle of risk balancing - especially risky capital investments need to be financed from own funds;

- the principle of adapting to the needs of the market - it is very important to take into account the market situation and its dependence on the loans;

- the principle of marginal profitability - it is worth choosing those investments that give the maximum, marginal profitability.

The short-term financial plan is of particular importance for the port, as it allows analyzing and controlling liquidity taking into account all plans, and the reserves in it provide information on the required liquidity [21]. Thus, the financial strategy is extremely important for the implementation of the economic strategy of the enterprise. At the same time, it should be noted that for the last decade the innovation strategy in the ports have been given the same attention as the strategies of marketing and finance, which is explained by a number of reasons, among which are the following:

- the speed of the stages of the life cycle (both the port itself and services that it provides time reduction for the stages of the life cycle of the enterprise);

- the need to produce a significant number of service modifications in order to extend the life cycle;

- orientation to market novelties that contain latent requirements of consumers, that is, on a proposal with fundamentally new qualitative parameters.

In conditions of global competition, the port should offer its customers services on more acceptable terms than its competitors, not only in price, but also in non-price factors [22]. Innovations in this direction are of great importance. From this point of view, the concept of "innovation" began to include not only purely technical research and development, but also all changes in the port's working style in order to increase competitiveness.

All kinds of innovations represent a decisive component of the economic strategy for the development of the port and they are the exclusive sphere of activity of the management [23].

In our opinion, the following factors influence the formation of the innovative port strategy in the direction of implementing the economic strategy:

1. Industry affiliation. Many enterprises proceeding from the specifics of their activities constantly invest considerable funds in scientific development and innovative projects.

2. The company's competitive strategy determines the value orientation of the investment of funds for the formation of the investment structure. Competitive strategy of differentiation involves investing in development, marketing research and production of new products; expansion of their range and creation of a large number of modifications; the organization of new methods of delivery of goods, its maintenance, etc. Thus, the investment structure in this case is aimed at achieving differentiation of products. In turn, the strategy of leadership in costs requires a constant investment in increasing production efficiency by acquiring modern equipment, replacing obsolete technologies, increasing the skills of personnel, etc.

3. The company's capabilities relate to the availability of financial resources and the ability of the company to carry out all stages, or any of them, of the "research-production-marketing" cycle. Financial constraints become a significant factor in budget planning and choice of innovative 
policy forms. Use or non-use at an enterprise of international standards ISO 9000 determines the potential opportunity and quality of the execution of the stages of the "research - production - marketing" cycle associated with the release of competitiveness products.

The functional strategy of the company includes marketing, innovation and financial strategy.

In the process of developing the production strategy, there is a reciprocal process of information exchange between the heads of all functional units that ensure the development and implementation of both functional strategies and an economic and competitive strategy.

Depending on the fluctuation of demand, the specifics of production and other factors, three strategic alternatives to the development of a production strategy are singled out:

1) complete satisfaction of demand - the company performs as many works as necessary in the market.

2) demand exceeds the capacity of the enterprise - the enterprise doesn't perform sufficient work; order, the enterprise can not perform, are transferred to other enterprises.

3 ) demand is lower than the capacity of the enterprise - the production capacities of the enterprise aren't fully used [24].

Currently, in most domestic ports, partial workload of production capacities is observed, to almost $60-70 \%$, in connection with this, when creating a production strategy, the main task is to ensure the full workload of existing production capacities [25]. In other words, the goal of the production strategy is to balance the available equipment, labor and scope of work. In this case, it is necessary to take into account the possibilities of using the equipment, its technical level, modernization or the need for reconstruction; rational placement of production equipment; rationing works; qualification potential and level of supply of the production process with labor resources.

Particular importance in the formation of the production strategy is paid to improve the quality of work. Improvement of the quality of work and reduction of production costs is the main goal of the port in modern conditions.

Functional strategies of the port are directly related to the implementation of the economic strategy and are of high priority for its successful implementation. Meanwhile, it should be noted that when implementing an economic strategy, great importance is given to other functional strategies, such as the social strategy, the strategy of organizational changes affecting the economic strategy of the port, primarily through the implementation of the first group of functional strategies.

The possibility of implementation of the functional strategies within the economic strategy of the port is inextricably connected not only with a set of purposeful actions, but also with the resource potential of the port and the features of the organizational and economic mechanism of the port management.

\section{Discussion of research results}

The conducted research confirmed the necessity and, at the same time, the exactingness with the use of a systematized approach to the formation of long-term programs for the development of enterprises in the port sector. The development of a functional strategy, by which the market strategy of an enterprise is implemented, determines the choice of behavior within a given function. The latter is an abstract concept reflecting the homogeneity of the various control operations. For example, the homogeneity of financial transactions (raising funds and dispose of them) is a financial function. In practice, the process of development of functional strategies is multistage, including the stages of agreement and coordination. Meanwhile, the delegation of the sphere of strategic decisions to lower functional levels contributes to the formation of an entirely new approach to the functioning of the organizational and economic mechanism of the enterprise and the expansion of opportunities in achieving the set goals imposes certain limitations and responsibilities. At the same time, the independent formation of functional strategies opens up reserves of efficiency of the enterprise's organizational and economic mechanism. Paying due attention to the functional strategy, it is possible to more effectively influence both the efficiency of any functional unit in the implementation of the company's economic strategy, and the amount of expenditures for unit financing. 
Functioning of port business areas in highly competitive environment requires essential decisions which should have outlined form on the form of development strategy of the selected term. The experience of the port over the years, having only declarative development strategies and programs, shows the urgent need to systematically generated and clearly structured strategy with defined stages for each sector and the service unit. This approach not only sets priorities and motion vectors for the future, and prescribes specific steps of timing tasks, responsible persons and estimates for development of established directions.

Works in these directions require sustained attention as environmental variability, especially outside, makes it impossible to build a "once and for all". Flexibility, dynamism, innovation, compliance with strict conditions of legislative and regulatory requirements are strengths of developed strategies, their viability and productivity.

\section{Conclusions}

Taking into account the results of the evolutionary development and patterns of transformation of the organizational and economic mechanism of the enterprises of the port sector, the basic principles for implementation of their market strategy are determined, based on the consideration of the organizational and economic mechanism from the standpoint of systemic and situational approaches, taking into account the instability and uncertainty of the external environment and the formation of priority objectives, aimed at rapid adaptation to unstable environmental conditions by adjusting the main provisions of the strategy.

The study of the content of "competitiveness" definition made it possible to determine the competitiveness of the port as an enterprise's ability to remain cost-effective in a competitive environment, by the presence of competitive competitors with similar goals and similar business-processes for achieving them. As the main criteria for determining the level of competitiveness, it is recommended to use the following: the possibility of retaining a stable longterm position in the market, an almost constant increase in profit and ensuring the desired and justified level of the company's capitalization. Depending on the state of development of the port and the stage of its life cycle, one of the above criteria can be chosen as the main result, and all together. Based on the results of the analysis, within the framework of this study, a certain algorithm and intermediate procedures for constructing an overall strategy for achieving the final result are proposed, providing the desired level of competitiveness of the enterprise in the port sector.

\section{References}

[1] Balabanova, L. V., Holod, V. V. (2006). Marketyngove upravlinnya konkurentospromozhnistyu pidpryyemstv: strategichnyj pidhid. Doneczk: DonDUET, 294.

[2] Brykova, I. V. (2007). Determinanty mizhnarodnoyi konkurentospromozhnosti nacionalnyx regioniv v globalnomu ekonomichnomu prostori. Mizhnarodna ekonomichna polityka, 7, 5-27.

[3] Eds. Gpadova, A. P. (1995). Ekonomicheckaja stpategija firmy. Saint Peterburg: Social'naja literatura, 414.

[4] Yermakova, O. A. (2008). Perspektyvy stvorennya transkordonnogo morskogo klastera v Chornomorskomu regioni. Available at: http://nbuv.gov.ua/j-pdf/econpr_2008_4_17.pdf

[5] Vidomenko, I. O. (2004). Zavdannya galuzevoyi konkurentnoyi polityky ta organizacijno-ekonomichnyj mehanizm realizaciyi strategiyi konkurenciyi. Ekonomika: problemy teoriyi ta praktyky, 196 (4), 932-937.

[6] Karlina, T. (2012). Stpuktura organizacii i konkurentnye preimushestva // Ppoblemi teorii i praktiki upravlinia, 6, 76-84.

[7] Mil'gpom, D. A. (1999). Ocenka konkurentosposobnosti ekonomicheckih tehnologij, Marketing v Rossii i zarubezhom, 2, 44-51.

[8] Porter, M. E. (2006). Konkurentnaja strategija: Metodika analiza otraslej i konkurentov. Moscow: Al'pina Biznes buks, 452.

[9] Gorbashko, E. A. (1994). Obecpechenye konkrentosposobnosty promishlennoj produkcyy. Saint Petersburg: SPbUEF, 178. 
[10] Gluxiv, A. V. (1999). Ocinka konkurentnozdatnosti tovaru i sposoby yiyi zabezpechennya. Marketyng, 2, 56-64.

[11] Chendler, A. D. (1962). Strategy and Structure: A Chapter in History of industrial Enterprizez. Cambridge, Mass, MIT Press, 724.

[12] Gorbachenko, S. A. (2015). Metodychni zasady formuvannya konkurentnyh perevag morskyh portiv Odeskogo region. Mizhnarodna ekonomika ta menedzhment, 1 (78), 131-138.

[13] Kibik, O. M., Zykharyeva, V. V. (2011). Formation of competitive advantage of enterprise marine transport of Ukraine. Ekonomichni innovaciyi, IPREED NANU, Ukraina, 45, 98-103.

[14] Dubovyk, N. V. (2012). Ocinka konkurentospromozhnosti pidpryyemstv servisnoyi diyalnosti na morskomu transporti. Rozvytok metodiv upravlinnya ta gospodaryuvannya na transporti, 4 (41), 166-185.

[15] Haralambides, H. E., Verbeke, A., Musso, E., \& Benacchio, M. (2001). Port Financing and Pricing in the European Union: Theory, Politics and Reality. International Journal of Maritime Economics, 3 (4), 368-386. doi: 10.1057/palgrave.ijme.9100026

[16] Primachev, N. T. (2009). Metody izmerenija effektivnosti morskogo transportnogo kompleksa. Odessa: ONMA, 258

[17] Stojanova, E. (1994). Finansovy menedzhment. Moscow: Perspektiva, 209.

[18] Chekalovec, V. I., Kolodin, A. L., Stoljarov, G. P. at. al. (2002). Sovershenstvovanie upravlenija morskimi torgovymi portami. Odessa: ONMU, 142.

[19] Karlof, B. (1991). Delovaja strategija. Moscow: ekonomika, 239.

[20] Eds. Kotlubaja, O. M. (2011). Konkurentospromozhnist' ta stalij rozvitok moregospodars'kogo kompleksu Ukraïni. Odesa: IPREED NAN Ukraini, 427.

[21] Kravchenko, A. V. (2008). Analiz rezul'tatov razvitija predprijatija portovoj dejatel'nosti. Rozvitok metodiv upravlinnja ta gospodarjuvannja na transporti, 27, 63-70.

[22] Chekalovecz, V. I., Olefir, I. M., Pustovit, O. G. (2004). Restrukturyzaciya portovogo gospodarstva Ukrayiny: problemy, pryncypy ta osnovni napryamky. Ekonomist, 2, 42-45.

[23] Stopford, M. (1988). Maritime Economics. London: Harper Collins Academic, 255.

[24] Petrov, A. N. (1992). Metodologija vyrabotki strategii razvitija predprijatija. Saint Peterburg: SPbUZF, 127.

[25] Cherednychenko, V. V. (2013). Osnovni chynnyky konkurentospromozhnosti ukrayinskyx portiv v umovax globalizaciyi. Efektyvna ekonomika, 10. 